\title{
Conflict Resolution Towards a Sustainable Peace: A Lesson from The Indonesian Military Ordinariate
}

\author{
Rofinus Neto Wuli (Corresponding author) \\ Graduate School of Management Jakarta National University, Indonesia \\ E-mail: 141167rnw@gmail.com
}

Muchlis R Luddin

Department of Management, Jakarta National University, Indonesia

Thomas Suyatno

Department of Management, Jakarta National University, Indonesia

Received: Jul. 8, 2019 Accepted: Aug. 9, 2019 Online published: Aug. 15, 2019

doi:10.5296/ijhrs.v9i3.15274 URL: https://doi.org/10.5296/ijhrs.v9i3.15274

\begin{abstract}
The diversity of tribes, religions, races, groups, and cultural expressions in various dimensions make Indonesia one of the most vibrant cultures in the world. However, it cannot be denied, that diversity has the potential to trigger social conflicts that can threaten the unity and unity of the nation and state and disrupt a safe and peaceful shared life. The long history of the Indonesian journey proves that social conflicts often occur due to the differences in ethnic groups, religious, racial background, and inter-group (SARA). Therefore, conflict resolution efforts are a necessity for Indonesia to realize a safe and peaceful shared life. This study was aimed to study the conflict resolution based on the history of the Indonesian Military Ordinariate in mitigating and resolving conflict. In general, there are two approaches to conflict resolution, namely intervention in security or stability and humanitarian intervention. Security interventions (stability) usually use military power to resolve conflicts, whereas humanitarian intervention integrates the strength of culture and local wisdom as a basis for resolving conflicts. Humanitarian intervention in resolving conflicts usually results in sustainable, peaceful reconciliation. A peace that occurs between the parties to the conflict is not due to compulsion under military pressure or State power but is born from the awareness of the parties to create mutually reconciling society.
\end{abstract}


Keywords: conflict resolution, servant leadership, religious norms, humanitarian approach

\section{Introduction}

Indonesia is a unitary state with many ethnic groups. From the Central Statistics Agency data released in 2012, there were around 1,128 tribes in Indonesia spread over more than 17,508, islands, 33 provinces, 514 districts/cities and a population of around 238 million people. Racial and ethnic groups diversity in Indonesia is increasingly complex with the diversity of cultures, religions, races, languages, between groups and various forms of cultural expression such as dances, songs, customs and social strata that are different from each other. Diversity, in its various dimensions, makes Indonesia one of the most vibrant cultures in the world.

However, on the other hand, diversity can potentially trigger social conflicts that can threaten the unity and unity of the nation and state and disrupt a safe and peaceful shared life. The potential for social conflict is increasingly complex because of differences in political choices, ideology, and regional egoism. It cannot be denied, that the long history of this nation's journey has never escaped conflict, both ethnic, religious, racial, and inter-group (SARA) conflicts and conflicts. Triggered because of ideological differences and wanted to separate from the Unitary State of the Republic of Indonesia (NKRI).

These conflicts not only claimed the lives of others but also caused long-term psychological trauma for the victims. Material losses and damage to necessary social infrastructure are also not counted. The Maluku conflict that occurred on January 19, 1999, for example, left around $8,000-9,000$ people dead. The conflict that lasted for four years also resulted in 29,000 houses being burned, 719 shops, 38 government buildings, and four banks destroyed. The house of worship was not spared from the mass rage. About 45 mosques and 47 churches were destroyed (Bertrand, 2004). Whereas the Sampit conflict that erupted on February 18, 2001 and lasted for ten days is estimated to have killed 10,000 people, and hundreds of thousands of Madurese were driven out of Kalimantan (Bertrand, 2004). The bloody conflict also destroyed many public facilities and houses. Furthermore, the Poso conflict that occurred towards the end of 1998 to 2001 is estimated to have claimed the lives of around 5,000 people (Bertrand, 2004). The various forms and variations of the conflict claimed not only lives, but also material losses that were not counted. Therefore, efforts to resolve conflict through humanitarian intervention are a necessity for Indonesia for the realization of a safe and peaceful shared life.

\section{Objective}

Commitments to conflict resolution have consequences that are not light, and even demand a kind of total self-sacrifice. Because conflict resolution is not looking for win-lose, but a solution that can be accepted by all parties (win-win solution). Therefore, conflict resolution must be open, inclusive and encourage conflict parties to talk and listen to each other in order to build mutual trust, thus enabling the achievement of an agreement to solve problems through peace. Conflict resolution must be able to provide space for conflict parties to actively participate in order to find meeting points to resolve problems. What is emphasized in conflict resolution is the balance between improving relations and solving problems 
(Barnes, 2005).

This paper will discuss the lesson of conflict intervention and resolution from the Indonesian Military Ordinariate (Ordinariatus Castrensis Indonesia/OCI). The main objective of this study was to study the experience and lessons from various conflict resolution done by the OCI, and to develop a frame conflict management of toward a sustainable peace resolution.

\section{Literature Review}

\subsection{Conflict Resolution}

The transformation of conflict through conflict resolution towards the creation of peace is not as easy. In addition to understanding, analyzing, and discovering the productive values of conflict, conflict resolution must be able to build social capacity, which is the foundation for sustainable reconciliation and social rehabilitation. It is essential to act honestly to others without distinguishing ethnicity, religion, race, or inter-group in order to create a safe, peaceful home and harmonious, sustainable reconciliation and neighboring life. Therefore, productive conflict resolution requires approaches that ensure a harmonious process of healing and social integration among the parties to the conflict.

Peace or reconciliation which is the estuary of conflict resolution is not as a compromise or pseudo-peace (Galtung, 1996), but an achievement that breaks down the wall of difference and the end of social conflict that leads to acts of violence that harm all parties. In conflict resolution, there are negotiations, compromises, and mutual agreements. In conflict resolution, differences and similarities about interests are processed to find common ground and agreements that can be accepted by all parties and considered fair by the parties to the conflict. Thus, conflict resolution, as a peaceful strategic of approach must be able to build mutual trust (trust), facilitate conflict resolution (dispute), ease tension, and reduce distrust. If this condition can be created, then the opportunity for the realization of peace and sustainable reconciliation among the conflicting parties is tremendous (Abubakar and Bamualim, 2006).

Conflict resolution is a standard method that is considered adequate for conflict resolution. However, for its success, we need governance and work procedures that guarantee the realization of peace and sustainable reconciliation. According to Galtung, every social conflict has a different level of conflict resolution because it has different risks and constraints. However, he stressed that conflict must be resolved at the level of empathy exchange and reach an agreement. Every conflict must reach the stage of solving problems (Galtung, 1996). Galtung "transcend approach," where the conflicting parties must get out of limitations (Galtung, 1996). They must break down the walls of personal or group egoism and openly agree to create conditions for neutral corridors and canals for everyone to freely express their opinions, without any psychological obstacles in any form. Thus, there will be empathy, mutual trust, solidarity, and a spirit of brotherhood, which ultimately erodes all differences in interests and the realization of sustainable, peaceful reconciliation.

However, to get out of the wall of selfishness and create opportunities for empathy is not easy. Suspicion, apathy, arrogance, and self-esteem of each party in conflict can be a psychological barrier to openness, thus limiting the will to solve problems. To bridge the conflicting parties, 
it is essential for third parties as mediators. Parties to the conflict can accept third parties because of their neutrality. Third parties can encourage parties to the conflict not to commit violence, choose a dialogue path, and resolve problems fairly to the roots (Galtung, 1996). Third parties also encourage the creation of reconciliation as the estuary of conflict resolution.

To achieve a common understanding of the root causes and sources of conflict, a third party or mediator needs to have an initial dialogue with the parties to the conflict. Mediators, both individuals, and institutions that are trusted by the conflicting parties must obtain as complete information as possible about the issues that are the source of conflict. Furthermore, the mediator must understand the attitudes, positions, desires, and expectations of each party in the conflict and try to find a meeting point to solve the problem.

The duration of the mediation process itself cannot be predicted, because it depends on the complexity of the background of the source of the conflict, the expertise of the mediator and the openness of the parties to forgive one another and try to knit a reconciling brotherhood. Likewise, with the mediation, it does not always end satisfactorily with the peaceful reconciliation of the parties to the conflict. If there is a deadlock in conflict resolution, the mediator cannot be blamed. (Widjojo, 2010).

\subsection{Towards a Sustainable Peace: Security and Humanitarian Approach}

Conflict resolution that opens a space for dialogue and fosters mutual trust, solidarity, and a strong desire to knit mutually reconciling brotherhood should lead to sustainable, peaceful reconciliation. Peaceful reconciliation is a crown of a long process that may take a long time to unite all differences and simultaneously build a culture of peace in the community based on the principles of constructive inter-human relations, namely: trust, integrity, tolerance and spirit of unity (Galtung, 1996).

Reconciliation comes from Latin words, reconciliation, which means to unite friendship or be friends again after being interrupted for a long time because of conflict. Reconciliation aims to unite various parties who have experienced a breakdown of friendship, to unite once more friendship between them (Wuli, 2019). The question is how to create a culture of peace amid a group or community that has conflicted using violence.

According to Muller-Fahrenholz, reconciliation is a deliberate act of parties who have conflicted to look for possibilities to improve memories that are filled with violence (Muller-Fahrenholz, 2002). Reconciliation never intends to find fault with the other party or sentence the perpetrators of violence but seek a meeting point for the realization of peace as the culmination of reconciliation. Because in the terminology of reconciliation is contained a group of values (human values), which can transform the selfish society into a society that is solid, loving, and tolerant. Conflict resolution fosters mutual trust, integration, and tolerance for diversity, thus strengthening national unity and a safe and peaceful shared life.

The power of reconciliation lies in whether you forgive and forgive those who have been in conflict. In reconciliation, the conflicting parties do not necessarily forget the past, but wisely take the wisdom from the conflict by forgiving and forgiving the painful event and designing 
a better future based on reconciling brotherhood.

Therefore, reconciliation is basically a reflection of conscience that presents togetherness, social solidarity, a sense of mutual need, mutual assistance, mutual reinforcement, mutual protection and mutual benefit both in family life, community / group, and the nation and state while respecting dignity, fellow freedom and autonomy as children of the nation. Reconciliation breaks down barriers of difference and fosters social solidarity and a culture of peace in a pluralistic society.

Reconciliation is different from negotiation. In reconciliation, people do not just gather and talk. Reconciliation talks about the transformation of consciousness where conflicting parties can meet personally to create a new culture (Muller-Fahrenholz, 2002). This is only achieved when the past conflicts are approached rather than looking for the wrong, but the effort to remove the burden of the past that blocks and creates a new history based on brotherhood and sustainable peace.

In reconciliation, perpetrators and victims of past violence meet to create peace in the future. They agreed to end the burden of history as victims and perpetrators of violence to improve relations that have already broken up (Wuli, 2019). They also agreed to end the pattern of violence used in resolving conflicts by knitting mutually reconciling brotherhood or social solidarity built on humanistic values such as honesty, peace, brotherhood, mutual cooperation, solidarity, cooperation and prioritizing the public interest in for personal or group interests and always try to create corridors and canals that allow each to express himself in accordance with the talents and talents given by God Almighty for the common good (bonum commune).

Peaceful reconciliation, which is the dream of the conflict parties, is achieved through a process called conflict intervention. In general, conflict intervention is associated with a series of empowerment activities for groups in conflict by relying on effective and appropriate conflict theories and methodologies in order to realize reconciliation (Malik et al., 2007). Conflict interventions aim to provide capacity, energy, or additional guidance so that the conflict resolution process (in which conflict reconciliation) continues. Of course, conflict interventions take into account what you want to achieve, the process to be achieved, and the objectives achieved in conflict intervention. Here conflict intervention is associated with the whole process of conflict transformation, so that conflict intervention is linked to the direction and purpose of conflict reconciliation (Wuli, 2019).

The idea of conflict intervention is not new. It is a normal process to deal with conflicts that occur. What is interesting is the model or style of approach to conflict intervention (Malik, 2008). There are two models or styles of approach in conflict intervention, namely: a security/stability approach and a humanitarian approach. The two approaches to conflict intervention remain result oriented, but the process and implications on the field are different.

The security/stability approach usually uses military power or a structural (power) approach from the state (state actor) to ease conflict. The parties to the conflict seemed to be forced to carry out peaceful reconciliation. The security approach is useful in ending the conflict. However, on the other hand, the security approach often does not touch the root of existing 
problems and is very vulnerable to acts of violence and human rights violations (HAM) by military or state officials (Al Araf et al., 2011). This approach left grief and tears and prolonged psychological trauma in the community involved in the conflict.

Moreover, the legal settlement of the conflict that has occurred has not been resolved and has not touched the sense of justice of the community. In the short term, security approaches can overcome conflicts and create peaceful reconciliation. However, peace reconciliation is artificial and unsustainable because it does not involve the actors involved in the conflict. Even the psychological trauma experienced by the parties involved in the conflict will grow the seeds of hatred and revenge that can explode at any time, especially if there are parties who provoke.

Whereas humanitarian intervention focuses more on peaceful dialogue to stop the conflict. In the humanitarian approach, the conflicting parties are treated as equal partners. The humanitarian intervention uses cultural values and local wisdom that grow and develop in the community as neutral corridors and canals that allow all parties to participate in resolving conflicts in order to realize sustainable, peaceful reconciliation. The parties are also invited to explore all issues to their roots and find a meeting point for conflict resolution.

The humanitarian approach model in conflict intervention is fundamental, not only to foster social harmony and solidarity but also to build the same vision, perception, and commitment of the parties in conflict in resolving conflicts between them (Malik, 2017). Humanitarian intervention rejects peace only as a non-violence situation, but as sustainable reconciliation where all people coexist peacefully, respectfully, tolerant of differences, integration, and always foster a spirit of unity and unity.

The different approaches to security and the humanitarian approach to conflict intervention are clearly illustrated by Will Kymlicka in his analysis of conflicts between majority-minorities in Eastern Europe (Kymlicka, 2004). As in other places, in Eastern Europe conflicts of interest between majority and minority are unavoidable facts of life. Minorities demand equal recognition from the majority in all aspects of life. Kymlicka compared intervention conflicts in Western Europe and Eastern Europe, which were generally fractions of the communist state of the Soviet Union (Kymlicka, 2004). From the results of his analysis, Kymlicka argues that there are differences in approaches to conflict intervention in Eastern Europe and Western Europe. In Eastern Europe, minority demands were seen as a threat to the stability of the country, whereas in Western Europe, the demands of minorities were part of the democratization process (Kymlicka, 2004).

According to Kymlicka, the difference in the approach lies in differences in perception and civilization (Kymlicka, 2004). In Western Europe, which was influenced by the notion of liberalism, it was more open to differences than in Eastern Europe. In Western Europe, minority demands are accepted according to the terms of justice (Kymlicka, 2004). The aim is to find more equitable accommodation between the majority and the minority. Many countries in Western Europe accept that justice requires some form of self-government for minorities. Whereas in Eastern Europe use a stability or security approach in the face of minority demands. The aim is to ensure that minorities do not threaten the life or territorial 
integrity of the country, and almost all in Eastern Europe believe that self-government for minorities is a threat (Kymlicka, 2004). From the description above, it can be said that Western Europe uses a justice/humanitarian approach, while Eastern Europe uses a security/stability approach.

\section{Methodology}

This study was a qualitative research that used narrative inquiry method (Daiute and Lightfood, 2004) that has been used to learn and understand the perspective of servant leadership to manage conflict (Earnhardt, 2008; Jit et al., 2016). The narrative inquiry method was used to gather data from conservations, interviews, life experiences as sources of data (Clandinin and Connelly, 2000). Data received from the results of observations, interviews, or research documentation must ensure validity or validity. The so-called validity of data is that the data collected is free from the subjectivity of the researcher as a research instrument, or subjectivity of interviews or informants. To achieve the validity of the data, the data is examined by considering credibility, transferability, dependability, confirmability.

Data that has been guaranteed its validity needs to be analysed to obtain abstractions that lead to meaning. Analysis of the data used in this study using interactive analysis techniques. In this technique, four critical components must be considered in conducting data analysis: data collection, data reduction, data presentation, and conclusion drawing. The samples of this study were 175 Indonesian Army and National Police staff from four major army base in Indonesia (Jakarta, Bandung, Ambon, and Pontianak), the detail of the sampling will be presented in Table 1. This study used semi structured interviews in a Focus Group Discussion (FGD) with Army and National Police Staff.

Table 1. Sampling of The Study

\begin{tabular}{lll}
\hline Location & Date & Number of Participants \\
\hline Jakarta, Indonesia & December $7^{\text {th }} 2018$ & Male staff: 33 \\
& & Female staff: 28 \\
Ambon, Indonesia & December $11^{\text {th }} 2018$ & Male staff: 23 \\
& & Female staff: 7 \\
Bandung, Indonesia & February $1^{\text {st }} 2019$ & Male staff: 25 \\
& & Female staff: 12 \\
Pontianak, Indonesia & May $3^{\text {rd }} 2019$ & Male staff: 26 \\
& & Female staff: 21 \\
\hline
\end{tabular}

\section{Results and Discussion}

The unique and challenging configuration of Indonesia with demographic features, anthropology, and a very diverse historical background are often sources of conflict. The conception of the nation-state which was initially expected to be able to connect Indonesian-style cultures and religions, as well as the nation's integration, aspired under the auspices of the Pancasila and the 1945 Constitution, did not seem to produce the expected results. The rise of various types of conflicts in several regions, especially since the beginning of the reform era in 1998 as described earlier, is evidence that the life of the community, 
nation, and state in this country is prone to conflict. This condition shows fragility in the process of becoming a nation (nation-building) in Indonesia. The national consensus consisting of Pancasila, the Indonesian 1945 Constitution, Indonesian national motto of Bhinneka Tunggal Ika (Unity in Diversity) and Indonesian National Unity as plural adhesive as a nation that is safe and peaceful has not been fully experienced by all components of Indonesian society.

To deal with the various forms and types of conflicts that occur, Indonesia designed a conflict intervention policy that referred to the mandate of the state constitution, namely the Preamble of the 1945 Constitution which explicitly set Indonesia's national interests as a top priority. In paragraph IV of the Preamble of the 1945 Constitution, it is stated that Indonesia's national goal is to protect the entire Indonesian nation and all of Indonesia's bloodshed, promote public welfare, educate the nation's life, and participate in carrying out world order based on freedom, eternal peace, and social justice.

The implementation of conflict intervention policies is linked to Indonesia's national security policy in the overall National Defense System (Sishanneg). In Sishanneg's perspective, conflict is accepted as a condition of disruption of relations between countries (foreign) and between community groups (domestic) which develop in the negative spectrum (Wuli, 2019). Results from the FGD done in this research further corroborate the Sishanneg perspectice. In particular, the diversity of ethnicity and religion in Indonesia, especially in those conflict prone area such as Aceh and Papua, the conflict is more between community groups. As one of participant of FGD from the Indonesian Police Force (Co-Chancellor of the Indonesian Military / Polri Gartap II / Bandung) stated "In the West Kalimantan region, tension between native Dayak ethnicity and the migrated Madura ethnicity is quite volatile. This is due to the past conflict events between those two ethnic groups that contrast in culture. Hence, the Police Force must be extra cautious and pro-active in the approach to the diverse community of West Kalimantan to mitigate conflict that may arise". Participants from the FGD held in Jakarta also stated that in Indonesia, the plurality of language, ethnic, religion, and tradition in Indonesia could trigger conflict between Indonesian. However, these pluralities must not treated as threat to the national security, but more as the important vision of tolerance and unity in Indonesia.

The Indonesian National Defense System is regulated in Chapter XII of Article 30 of the 1945 Constitution concerning Defense and State Security, Law No. 3 of 2002 concerning National Defense, Law No. 34 of 2004 concerning the Indonesian National Army, Law No.7 of 2012 concerning Handling Social Conflict, and Presidential Instruction No. 2 of 2013 concerning Handling of Internal Security Disorders. The soul of the laws and regulations guarantees the sovereignty of the Unitary State of the Republic of Indonesia based on Pancasila and the 1945 Constitution and the realization of a safe, peaceful community, nation and state life that is tolerant of pluralism and upholds the unity in the Indonesian Community. All of the participants in the FGD held by this research uphold the value of Pancasila and the 1945 Constitution as the main vision of their jobs to ensure the Indonesian national security. As one of the participants (Brigadier General Sri of Deputy Region West Kalimantan Police) stated "the way of life for military soldier and police officer in Indonesia must refer to the 
spirit of Pancasila as National Identity, and the 1945 Constitution as the fundamental regulation that govern Indonesian People to create a strong bonding between the diverse community of Indonesian".

During the New Order in power (where President Soeharto was in power during the 1980s-1990s), conflict intervention was more dominant using a security/stability approach by placing the military and police as the main actors to reduce conflict. The involvement of the military and police in dealing with conflict is not without problems. A security approach that is not accompanied by a deep understanding of the source of the problem even creates a negative impact on communities in conflict areas. The negative impact was in the form of acts of violence, intimidation, arbitrary detention, unlawful killings, sexual harassment, and various forms of human rights violations which left psychological trauma for people in conflict areas. Most of the participants in the FGD shared their view on this matter and further agree that the security/stability approach done in the past was more harmful to the fragile peace condition in a conflict zone area. The general opinion was that conflict intervention should be done using humanitarian approach, where dialogue and negotiation is important to understand the source of the conflict. As one of the participants from the FGD (Colonel Inf. from the Dirbinum Pussenif Kodiklatad, Bandung) stated "conflict resolution through a peaceful humanitarian approach is indeed not easy. It takes extra time and patience to unite different perceptions and beliefs from the conflicting parties. However, when differences in perceptions, beliefs, and conflicts of interest can be bridged through dialogue and negotiation, then the peace that occurs will be sustainable".

The Aceh and Papua conflicts, for example, prioritize a security approach. This can be seen from the policies of the New Order government of Indonesia, which established Aceh and Papua as Areas of Military Operations (DOM). The security approach in Aceh and Papua did not resolve the conflict; on the contrary, the resistance of armed groups in Aceh and Papua never subsided. They continue to carry out security disturbances. The arrest and killing of separatist groups did not stop the separatist struggle. The Aceh conflict was finally handled through negotiations and ended at the negotiating table between the Indonesian government and the Free Aceh Movement (GAM) in Helsinki on 15 August 2005. Aceh was made a specialized area. While the Papua conflict to date has not been completed. Security problems often occur. However, the security approach began to be minimized by the revocation of DOM status in Papua. The resistance group is no longer called the Free Papua Organization (OPM), but as the Armed Criminal Group (KKB). Papua was given the status of a special autonomy (Otsus) area since 2001. Implementation of development in Papua was carried out in the form of infrastructure development, the application of one price for basic needs throughout Papua and improving the quality of Papuan human resources through education (formal and non-formal).

The paradigm shift in handling social conflicts has an impact on patterns of conflict intervention. Conflict handling is carried out comprehensively through three stages covering aspects of prevention, termination, and post-conflict recovery. This policy is regulated in Law No. 7 of 2012 About Social Conflict Management. While the handling of internal security disturbances is regulated in Presidential Instruction (Inpres) No. 2 of 2013. The Inpres 
stipulates that to deal with domestic conflicts it is necessary to establish a Central Level Integrated Team and Regional Level Integrated Teams by including all relevant elements, in order to ensure the presence of command and control unity, as well as clarity of objectives, action plans, officials responsible for each - individual problems, as well as completion time targets. The President also instructed through this Inpres to take quick, appropriate and decisive steps to stop all forms of violence due to social conflict and terrorism, while still prioritizing legal aspects, respecting local norms and customs, and upholding values human rights (HAM) (Wuli, 2019).

From the description above, it can be said that Indonesia combines a security and humanitarian approach in the intervention of conflict in the country. When a country is in an escalating spectrum of threats and develops in a direction that threatens national security, a mechanism for the involvement of national power elements in two functional approaches is needed, namely non-military defense (civil) and military defense functions (Ministry of Defense, 2008). Security interventions are of an emergency to prevent the widespread intensity of conflict and the area of its spread. Humanitarian intervention must be a priority by integrating a culture-based dialogue approach, local wisdom, and religion to ensure mutual social integration and brotherhood. Therefore, every member of the community must live the virtues in the life of the nation and state, among others: (a) developing an attitude of tolerance and mutual respect for the freedom of worship in accordance with their religion and beliefs; (b) respecting the freedoms of tribes, languages and customs of others; (c) recognize and treat human beings according to their dignity and dignity; (d) recognize equality and equality of rights and fundamental obligations of every human being regardless of ethnicity, descent, religion, belief, gender, social position, and skin color; and (e) developing Indonesian unity on the basis of diversity and unity (Indonesian Regulation Number 7/2012).

Changes in the conflict intervention paradigm have not yet gone hand in hand with changes in the behavior of security forces. Experience has proven, the security approach is still carried out by the government in resolving horizontal conflicts. Humanitarian approaches through culture and mediation in resolving conflicts are often underestimated. Even though the community has the power of culture and local wisdom and religious values that are noble to create social integration and the realization of sustainable, peaceful reconciliation, thus, cultural values, local wisdom, and religion can be a national power as social capital that can fuel the spirit of unity and unity as a nation in the frame of the Republic of Indonesia based on Pancasila and the 1945 Constitution. Political power is the basis always inject new energy for all components of a pluralistic society for peacebuilding and the realization of a culture of peace and sustainable reconciliation (Brouneus, 2003).

\section{Conclusion}

In heterogeneous societies such as in Indonesia, the potential for social conflict is quite high. Conflict of interest and differences in political and ideological choices can lead to conflicts that not only disrupt the harmony of life together and cause casualties and material that are not small but can also threaten the sovereignty of the Unitary State of the Republic of Indonesia. The track record of the history of the journey of the Indonesian people since the 
proclamation of the independence of the Republic of Indonesia on August 17, 1945, to the present, shows how fragile the life of the nation and state. A series of social conflicts based on ethnicity, religion, race, and heartbreaking groups occurred in a number of regions. Even the movement that wanted to undermine the Unitary State of the Republic of Indonesia based on Pancasila and the 1945 Constitution also took place in this country.

In responding to social or political conflict, Indonesia conducts conflict resolution by combining security/stability interventions and humanitarian interventions to achieve sustainable, peaceful reconciliation. So far, there is an impression that the security/stability intervention is more dominant than humanitarian intervention, especially during the New Order government. Security/stability interventions are effective in reducing conflict, but on the other hand, leave grief, tears, and psychological trauma for people in conflict areas. Unjust and arbitrary treatment, as well as traumatic experiences, trigger the cumulative grudge of society. Like a fire in a husk, the cumulative revenge will erupt at any time, especially if there are parties who provoke it.

Therefore, since the 1998 reformation, there has been a paradigm shift in conflict intervention in Indonesia. Conflict resolution is ahead of humanitarian interventions through dialogue and knitting brotherhood that reconciles each other by creating a neutral corridor and canals, where all diversity is united. Humanitarian intervention integrates the strength of culture, religion, and local wisdom in resolving conflicts. Through humanitarian interventions, the parties in conflict are treated equally and seek meeting points that are acceptable to all parties. In humanitarian interventions, the parties in conflict agree to forgive the past that hurts togetherness, and both want to build a better and more peaceful future.

Humanitarian intervention in the context of the realization of sustainable peace must be promoted through peace education to children from an early age and youth through local community organizations. The internalization of human values, culture, local wisdom and religion is expected to form a strong character of the nation, which places the interests of the nation and the state above the interests of the group and upholds the unity and unity of the nation in the spirit of Bhinneka Tunggal Ika (Unity in Diversity), so that reconciliation and peace are realized sustainable, which is the dream of all parties.

\section{References}

Abubakar, I., Bamualim, C. S., \& Malik, I. (2006). Modul resolusi konflik agama \& etnis di Indonesia. Jakarta: Pusat Bahasa dan Budaya, Universitas Islam Negeri Syarif Hidayatullah Jakarta.

Araf, A., Aliabbas, A., Manto, A., Reza, B. I., Satriya, C., Mahruri, G., .. \& Indarti, P. (2011). Sekuritisasi Papua: Implikasi Pendekatan Keamanan terhadap Kondisi HAM di Papua. Jakarta: Imparsial.

Barnes, H. (2005). Conflict, Inequality and Dialogue for Conflict Resolution in Latin America: The Cases of Argentina, Bolivia and Venezuela (No. HDOCPA-2005-03). Human Development Report Office (HDRO), United Nations Development Programme (UNDP). 


\section{Macrothink}

International Journal of Human Resource Studies

ISSN 2162-3058 2019, Vol. 9, No. 3

Bertrand, J. (2004). Nationalism and ethnic conflict in Indonesia. Cambridge University Press. https://doi.org/10.1017/CBO9780511559341

Brounéus, K. (2008). Reconciliation: Theory and practice for development cooperation. Stockholm: Swedish International Development Cooperation Agency.

Clandinin, D. J., \& Connelly, F. M. (2000). Narrative inquiry. San Francisco, CA: John Wiley \&Sons.

Earnhardt, M. P. (2008). Testing a servant leadership theory among United States military members. Emerging Leadership Journeys, 1(2), 1-14.

Galtung, J. (1996). Peace by peaceful means: Peace and conflict, development and civilization (Vol. 14). Sage.

Jit, R., Sharma, C. S., \& Kawatra, M. (2016). Servant leadership and conflict resolution: A qualitative study. International Journal of Conflict Management, 27(4), 591-612. https://doi.org/10.1108/IJCMA-12-2015-0086

Kymlicka, W. (2004). Justice and security in the accommodation of minority nationalism. Ethnicity, nationalism and minority rights, 144-175. https://doi.org/10.1017/CBO9780511489235.008

Malik, I. (2008). Peace building and conflict prevention. Jakarta: Serap.

Malik, I. (2017). Resolusi konflik, jembatan perdamaian. Jakarta: Penerbit Buku Kompas.

Malik, I., Kusumadewi, L. C., \& Widyanti, S. (2007). Bergerak Bersama Mencegah Konflik: Panduan Praktis untuk Peringatan dan Tanggapan Dini Konflik Berbasis Jaringan dan Komunitas. Jakarta: Yayasan Tifa Jakarta.

Muller-Fahrenholz, G., Kirchberger, G., \& Beding, B. (2005). Rekonsiliasi: upaya memecahkan spiral kekerasan dalam masyarakat. Ledalero.

Widjojo, M. S., Elizabeth, A., Al Rahab, A., Pamungkas, C., \& Dewi, R. (2010). Papua road map: Negotiating the past, improving the present, and securing the future. Jakarta: Yayasan Pustaka Obor Indonesia.

Wuli, R. N. (2019). Spirit Kebangsaan Prajurit Dalam Perspektif Spirituali Militum Curae. Jakarta: Penerbit Obor.

\section{Copyright Disclaimer}

Copyright for this article is retained by the author(s), with first publication rights granted to the journal.

This is an open-access article distributed under the terms and conditions of the Creative Commons Attribution license (http://creativecommons.org/licenses/by/4.0/). 